\title{
Effect of native and modified starches on nutritional and physiological performance of wild juveniles of red grouper (Epinephelus morio)
}

\section{Efecto de almidones nativos y modificados sobre el desempeño nutrimental y fisiológico en los juveniles silvestres del mero rojo (Epinephelus morio)}

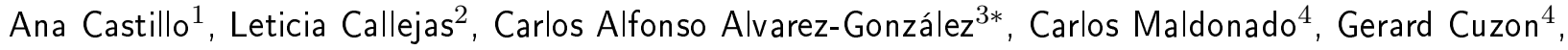 \\ Gabriela Gaxiola* ${ }^{4 *}$ \\ ${ }^{1}$ Posgrado de Ciencias del Mar y Limnología, Universidad Nacional Autónoma de México (UNAM), México. \\ ${ }^{2}$ Facultad de Medicina Veterinaria y Zootecnia, UNAM, México. \\ ${ }^{3}$ Laboratorio de Acuicultura Tropical, DACBIOL, Universidad Juárez Autónoma de Tabasco, México. \\ ${ }^{4}$ Unidad Multidisciplinaria de Docencia e Investigación de Sisal, Fac. de Ciencias, UNAM, México. \\ *Corresponding author: alvarez_alfonso@hotmail.com, mggc@ciencias.unam.mx
}

Scientific article received: July 07, 2017 accepted: May 21, 2018

\begin{abstract}
The aim of this study was to evaluate carbohydrates utilization by wild red grouper Epinephelus morio. Juveniles were fed during $93 \mathrm{~d}$ on a selection of starches: native raw cornstarch (RCS), waxy cornstarch (WCS), raw potato starch (RPS) and gelatinized potato starch (GP) at $20 \%$ inclusion level. The best growth was obtained in fish fed cornstarch either native raw of waxy cornstarch $(p<0.05)$. Hepatosomatic index and blood glucose $(40 \mathrm{mg}$ $\mathrm{dL}^{-1}$ ) were similar as well as hematocrit values $(50 \%)(\mathrm{p}>0.05)$, whereas glycogen content increased up to 200 $\mathrm{mg} \mathrm{g}^{-1}$ with waxy cornstarch. Specific activity of $\alpha$ glucosidase and $\alpha$-amylase remained stable $(\mathrm{p}>0.05)$. Hepatic glycolytic enzymes increased with raw native and waxy cornstarch $(p<0.05)$; metabolic enzyme glucose 6 phosphate dehydrogenase $(\mathrm{G} 6 \mathrm{P}-\mathrm{DH})$ was activated with raw native cornstarch $(\mathrm{p}<0.05)$ while pyruvate kinase $(\mathrm{PK})$ remained stable regardless of treatments $(p>0.05)$. Hexokinase (HK1) and glucokinase (GK) varied according to carbohydrate source: values were higher with cornstarches than potato starches $(p<0.05)$. Pentose monophosphate shunt $(H M S)$ remained not altered by starch sources $(p>0.05)$. In final, the low size of granules from cornstarch favored the assimilation in liver of wild juveniles red grouper.
\end{abstract}

Key words: Grouper, digestive enzymes, glucose, glycogen, metabolic enzymes

RESUMEN. El objetivo de este estudio fue evaluar la utilización de carbohidratos en juveniles silvestres del mero E. morio alimentados con una selección de almidones: maíz crudo (RCS), maíz ceroso (WCS), papa cruda (RPS) y papa gelatinizada (GP). Los juveniles de peces se alimentaron durante $93 \mathrm{~d}$ con 4 dietas que se prepararon con $20 \%$ de nivel de inclusión de almidón. Se observaron diferencias significativas en el coeficiente de crecimiento térmico TGC ( $p>$ $0.05)$. Los mejores coeficientes se obtuvieron con el almidón de maíz crudo y ceroso $(p<0.05)$. El hematocrito $(50 \%)$, el índice hepatosomático y glucosa en sangre $\left(40 \mathrm{mg} \mathrm{dL}^{-1}\right)$ fueron similares $(\mathrm{p}>0.05)$, mientras que el contenido de glucógeno aumentó hasta $200 \mathrm{mg} \mathrm{g}^{-1}$ con el almidón de maíz ceroso. La actividad específica de $\alpha$-glucosidasa y $\alpha$-amilasa permaneció estable $(\mathrm{p}>0.05)$. Las enzimas glucolíticas hepáticas aumentaron en los peces alimentados con el almidón de maíz crudo y ceroso $(\mathrm{p}<0,05)$. La enzima glucosa 6 fosfato deshidrogenasa (G6P-DH) se activó con el almidón de maíz crudo $(\mathrm{p}<0.05)$. La piruvato cinasa $(\mathrm{PK})$ se mantuvo estable independientemente de los tratamientos $(p>0.05)$. La actividad hexocinasa (HK1) y glucocinasa $(G K)$ cambiaron con la fuente de almidón, siendo mayor en ambos almidones de maíz que los almidones de papa $(p<0.05)$. La ruta pentosa fosfato (HMS) permaneció sin alteración por las fuentes de almidón $(\mathrm{p}>0.05)$. En conclusión, el tamaño de partícula de gránulo inferior del almidón de maíz favoreció la asimilación en hígado de juveniles silvestres de mero rojo.

Palabras clave: Enzimas digestivas, glucosa y glucógeno, enzimas metabólicas, mero 


\section{INTRODUCTION}

Red grouper (Epinephelus morio) is a new candidate species for aquaculture and represents a commercial species in the Gulf of Mexico; however, overfishing led to a drop of the natural populations. E. morio belongs to Serranidae family and like other groupers, is considered a predator that fed on large variety of prey. In this sense, crabs are the most abundant prey in its stomach content; also shrimps, lobsters, cephalopods, and marine fish can be present (Giménez et al. 2001). This diversity of preys in the daily meals showed the great flexibility and opportunism at a trophic level where groupers can find an adequate nutrition (Schmitt 1986). Although, these studies present $E$. morio as a colossal carnivore, biochemical information on enzymes involved in digestion or intermediary metabolism enzymes related to feeding habits are scarce (Amirkolaie et al. 2005).

In relation to the nutrition of red grouper a previous work has been done (Silva et al. 2014) focusing on protein sources selection and requirement without consideration for dietary carbohydrates. However, dietary carbohydrate as an alternative to limit protein content in feed (Cowey and Walton 1989) were tested in carnivorous species such as Atlantic salmon Salmo salar (Hemre and Hansen 1998), gilthead seabream Sparus aurata (Metón et al. 2003, Enes et al. 2006, Fernández et al. 2007), snout bream Megalobrama amblycephala (Ren et al. 2015), European seabass Dicentrarchus labrax, (Peres and Oliva-Teles 2002), rainbow trout Oncorhynchus mykiss (Kirchner et al. 2005).

Utilization of carbohydrates depends on feeding habits: omnivorous fish exhibited a higher starch utilization compared to carnivorous fish; glucose or maltose dextrin was utilized faster than higher molecular form, such as starches that contain amylose and amylopectin $\alpha$-D (1-4)-glycosidic bonds (Wilson 1994). However, the digestion of the different starches depends also on the characteristics related to granule size: cornstarch ( 5 to $25 \mu \mathrm{m}$ ) can be digested better than potato starch (15 to100 $\mu \mathrm{m})$ (Buleon et al. 1998). The amylopectin content is also different: waxy and raw cornstarches with 99 and $73 \%$ content, and raw and gelatinized potato starches around $78 \%$. Amylopectin was found more soluble and stable in water solution and do not form starches resistant to digestion (Tharanathan 2002).

Considering the above-mentioned, wild juvenile's $E$. morio possess a carbohydrase activity in the pyloric caeca and intestine and will be able to digest dietary starches under controlled conditions. In this sense, to guarantee the effective utilization of glucose in the liver, it needs to be phosphorylated by hexokinase $(\mathrm{HK})$ with low $\mathrm{Km}(0.1 \mathrm{mM})$. Glucokinase isoform (HK IV) with high km (5-10 $\mathrm{mM}$ ) plays a regulator role for glycaemia (Metón et al. 2003, Enes et al. 2006) and the metabolic profile responded as an adaptation to various energy sources. The present study aim to the dietary acclimation of wild juvenile's $E$. morio and the effect of native and modified starches from various origins for digestion and intermediary metabolism.

\section{MATERIALS AND METHODS}

\section{Fish capture}

Epinephelus morio juveniles (initial mean body weight $109.2 \pm 2.4 \mathrm{~g}$ ) were captured along the coastal area of the Yucatán, Mexico, and after a short period of quarantine $(10 \mathrm{~d})$, fish were transferred to the experimental rearing unit consisting in 15 fiberglass cylindrical tanks ( $500 \mathrm{~L}$ of water capacity each) with recirculated water.

\section{Experimental design and diet composition}

To evaluate the different starches, a completely randomized design with four treatments and three replicates per treatment was set. Juveniles were set into experimental tanks and fed with four different diets for 93 days ( 3 tanks per diet; $n=30$ per treatment). The starches tested were: Native raw cornstarch (RCS), waxy cornstarch (WCS), raw potato starch (RPS) and gelatinized potato starch (GP) at a $20 \%$ of inclusion level. Crude protein 41-47\%; lipid 5-8\%; ash 13-15\%; Nitrogen free extract $26-29 \% ; 16-17 \mathrm{~kJ} \mathrm{~g}^{-1}$ (Table 1). The protein sources were selected according to Silva et al. 
Table 1. Composition of experimental diet $\left(\mathrm{g} \mathrm{kg}^{-1}\right)$ and parameters. Raw native cornstarch (RCS), waxy cornstarch (WCS), potato raw starch (PRS), gelatinized potato starch (GPS).

\begin{tabular}{|c|c|c|c|c|}
\hline & RCS & WCS & RPS & GPS \\
\hline Menhaden fishmeal $^{1}$ & 430 & 430 & 430 & 430 \\
\hline Shrimp meal ${ }^{2}$ & 50 & 50 & 50 & 50 \\
\hline Squid $^{3}$ & 50 & 50 & 50 & 50 \\
\hline Soy protein concentrate ${ }^{4}$ & 200 & 200 & 200 & 200 \\
\hline amino acids mix & 37 & 37 & 37 & 37 \\
\hline Raw corn starch 6 & 200 & & & \\
\hline Waxy corn starch ${ }^{7}$ & & 200 & & \\
\hline Raw potato starch 8 & & & 200 & \\
\hline Precooked potato starch ${ }^{8}$ & & & & 200 \\
\hline vit $+\min$ premix $^{10}$ & 15.3 & 15.3 & 15.3 & 15.3 \\
\hline Amylose: amylopectine ratio & $27: 73$ & $1: 99$ & $22: 78$ & $22: 78$ \\
\hline \multicolumn{5}{|c|}{ Proximate analysis ( $\%$ dry weight) } \\
\hline Moisture & 46.6 & 40.4 & 40.6 & 43.5 \\
\hline Crude protein & 53.0 & 53.1 & 54.1 & 53.2 \\
\hline Ether extract & 4.6 & 7.9 & 5.8 & 6.2 \\
\hline NFE & 29.6 & 25.9 & 25.9 & 25.9 \\
\hline Ash & 13.9 & 13.1 & 14.2 & 14.7 \\
\hline $\mathrm{kJ} \mathrm{g}^{-1}$ & 16.7 & 17.3 & 16.4 & 16.3 \\
\hline \multicolumn{5}{|c|}{$\begin{array}{l}{ }^{1} \text { Menhaden fishmeal APLIGEN. Special Selection; }{ }^{2} \text { Shrimp meal; } \\
{ }^{3} \text { squid, fishing crude; }{ }^{4} \text { Soy protein concentrate. WACHSEN; }{ }^{5} \text { LYS, } \\
\text { THR, LEU, TRP, Future Foods; }{ }^{6} \text { Raw Corn Starch. CP Ingredients; } \\
{ }^{7} \text { Waxy corn starch. WACHSEN; }{ }^{8} \text { Raw potato starch; }{ }^{9} \text { Aluminium sili- } \\
\text { cate }{ }^{10} \mathrm{DSM}\left(\mathrm{mg} \mathrm{kg}^{-1} \text { diet): A, } 18000 \text { (IU kg }{ }^{-1} \text { diet); cholecalciferol, }\right. \\
\text { Rovimix Stay-C } 35.13 \% ; 2000 \text { (IU } \mathrm{kg}^{-1} \text { diet); E, 35; Na menadione } \\
\text { bisulphate; B1, 15; B2, 25; Ca pantothenate, 50; nicotinic acid, 200; } \\
\text { B6, 5; folic acid, 10; B12, 0.02; biotin, 1.5; C, 50; inositol, } 400.11 \text {. } \\
\text { amino acids mix (LYS5 THR5 LEU5 TRP5: } 12,20,4,1 \text { respectively. }\end{array}$} \\
\hline
\end{tabular}

(2014). Macroingredients previously sieved $(<250$ $\mu \mathrm{m})$ and mixed with micro-ingredients during 15 min then $20-30 \%$ water added. The mixture was subsequently extruded through a meat mincer and collets dried to $10 \%$ and stored at $-20^{\circ} \mathrm{C}$ until fed. During the trial, fish were fed $3 \%$ body weight, by hand twice a day, 7 days a week and monitored monthly for biometry. Water temperature $27.2 \pm$ 1.1 in the morning and $27.6 \pm 0.9^{\circ} \mathrm{C}$ in the afternoon, salinity $37.4 \pm 0.1$ ups, dissolved oxygen 5.5 $\pm 0.3 \mathrm{mg} \mathrm{L}^{-1}$ were recorded.

\section{Zootechnical parameters}

Values displayed survival rate $(\%)$, thermal growth coefficient (TGC) daily calculated as: final body weight ${ }^{1 / 3}$-initial body weight ${ }^{1 / 3} /$ $\mathrm{T}^{\circ} \mathrm{C}^{*}$ number of days*100 (Cho 1992). Ingestion rate was calculated based on $3 \%$ biomass recalculated to convert into energy values (Table 1 ).

\section{Analytical methods}

At the end of growth experiment, 10 fish of each treatment were anesthetized with $0.1 \mathrm{mg}$ $\mathrm{mL}^{-1}$ clove oil poured in seawater and then sampled, blood collected from the caudal vein with a heparinized syringe, sealed in a capillary tube, centrifuged at $380 \mathrm{~g}$ for one hour (3 replicates per fish); hematocrit value is the volume occupied by circulating red blood cells in the blood expressed as a percentage of the total volume of blood (Daisley 1973). Glucose concentration was calculated with a standard curve of D-glucose $\left(1 \mathrm{mg} \mathrm{mL}^{-1}\right)$. To measure hepatic glycogen $60 \mathrm{mg}$ liver tissue weighed on an analytical balance (Ohaus Pioneer TM) followed the technique of Dubois et al. (1965). Stomach, liver, pyloric caeca and intestine dissected on ice were frozen at $-80^{\circ} \mathrm{C}$ for further biochemical analysis.

\section{Digestive enzyme activity}

Enzyme extraction was performed by 
disrupting pyloric ceca and intestine samples in distilled water using an Ultra Turrax IKA T18 (North Chase, Wilmington) then organs homogenized in pyrogen-free water at a ratio $1: 5(\mathrm{w} / \mathrm{v})$, centrifuged at $16170 \mathrm{~g}-4^{\circ} \mathrm{C}, 20 \mathrm{~min}$, supernatant removed and stored at $-80^{\circ} \mathrm{C}$ for biochemical analysis. Alphaamylase activity was measured with $2 \%$ starch as substrate and a citrate-phosphate buffer $100 \mathrm{mM}$, $\mathrm{NaCl} 50 \mathrm{mM}$ pH 7.5. Specific activity was expressed in $\mathrm{U} \mathrm{mg}^{-1}$ soluble protein (Robyt and Whelan 1968). Alpha-glycosidase activity was read at $415 \mathrm{~nm}$ with 4-nitrophenyl $\beta$-D-glycopyranoside as a substrate in a Na-phosphate buffer (Clark et al. 1984).

\section{Intermediary metabolic enzyme activity}

Liver was homogenized in $50 \mathrm{mM}$ Tris- $\mathrm{HCl}$ with $\mathrm{pH}$ 7.5, $4 \mathrm{mM}$ EDTA, $50 \mathrm{mM} \mathrm{NaF}, 0.5$ $\mathrm{mM}$ phenylmethylsulfonyl fluoride, $500 \mathrm{mM}$ 1,4dithiothreitol and $250 \mathrm{mM}$ sucrose and centrifuged at $16170 \mathrm{~g}$ for $30 \mathrm{~min}$ at $4^{\circ} \mathrm{C}$ in an Ultra Turrax IKA T18 (position 4, $10 \mathrm{~s}$ ). Activities of pyruvate kinase, EC 2.7.1.40, fructose-1,6-biphosphatase (FBPase1, EC3.1.3.11), glucose 6-phosphate dehydrogenase (G6P-DH, EC 1.1.1.43), and alanine aminotransferase (ALAT, EC 2.6.1.2) were assayed with crude liver extracts using a Bio-Rad Benchmark Plus microplate spectrophotometer (Bonamusa et al. 1992). Additionally, hexokinase 1 (HK-1, HK; EC 2.7.1.1), hexokinase 2 (HK-2, HK; EC 2.7.1.1) and glucokinase (GK, EC 2.7.1.2) activities calculated from a frozen liver sample homogenized $(1 / 5$ dilution) in an ice-cold buffer ( $80 \mathrm{mM}$ Tris, $5 \mathrm{mM}$ EDTA; $2 \mathrm{mM}$ dithiothreitol; $1 \mathrm{mM}$ benzamidine; 1 $\mathrm{mM}$ 4-2-aminoethyl benzene sulphonyl fluoride; sucrose $1 \mathrm{M}, \mathrm{KCl} 1 \mathrm{M}, \mathrm{pH}$ 7.6. After centrifugation (16 $170 \mathrm{~g}$ for $40 \mathrm{~min}$ at $4^{\circ} \mathrm{C}$ ), the supernatant was separated on a Sephadex G-25 column. Hexokinase (low $\mathrm{Km} \mathrm{HKs}$ ) and glucokinase (high $\mathrm{Km} \mathrm{HK}$ or HK IV) activities were measured using $1 \mathrm{M}$ and $100 \mathrm{mM}$ glucose respectively at $37^{\circ} \mathrm{C}$. The assay on glucokinase activity from frozen samples required a correction by measuring GDH (EC 1.1.1.47) activity (Tranulis et al. 1996), all enzyme assays analyzed at $30^{\circ} \mathrm{C}$, read at $340 \mathrm{~nm}$.

\section{Specific activity of enzymes}

Activities were expressed as Units per mg soluble protein from liver. Protein concentration (Bradford 1976) used a Sigma protein assay kit with bovine serum albumin as a standard; one unit of enzyme activity was defined as the amount of enzyme that catalyzed hydrolysis of $1 \mu \mathrm{mol}$ substrate per min at assay temperature.

\section{Statistical analysis}

A one-way ANOVA test was applied with survival percentages that were previously transformed to arcsine values. One block of the nested ANOVA $(p<0.05)$ assessed the significance for thermal growth coefficient, physiological parameters and intermediary metabolic enzymatic activities. Tukey multiple range test was applied when significant differences were observed. In absence of normality and homogeneity of variances of digestive enzymatic activities, a Kruskal-Wallis test helped compare treatments at a probability of 0.05 for all analyses (Statistica 7.0).

\section{RESULTS}

Diets containing starch had no incidence on ingestion rate $(p>0.05)$ but a positive correlation was observed between final wet weight and ingestion rate (Figure 1 ). TGC values were similar whatever treatment $(p>0.05$, Table 2). Diets containing starch had no incidence on ingestion rate $(p>0.05)$ but a positive correlation was observed between final wet weight and ingestion rate (Figure 1). TGC values were similar whatever treatment ( $p>0.05$, Table 2). Hematocrit (\%) was similar for all treatments $(p>0.05$, Table 3 ) as well as plasma glucose level $(p>0.05)$. Liver glycogen content peaked at $214 \pm 14 \mathrm{mg} \mathrm{g}^{-1}$ with waxy cornstarch $(p<0.05)$; hepatosomatic index did not change $(p>0.05)$. Specific activity of $\alpha$-amylase gave a mean value of $2768 \mathrm{U}$ and $448 \mathrm{U}$ for pyloric caeca and intestine respectively and $\alpha$-glycosidase (mean value $610 \mathrm{U}$ and 487 for pyloric caeca and intestine respectively did not differ whatever dietary treatment $(p>0.05)$. 


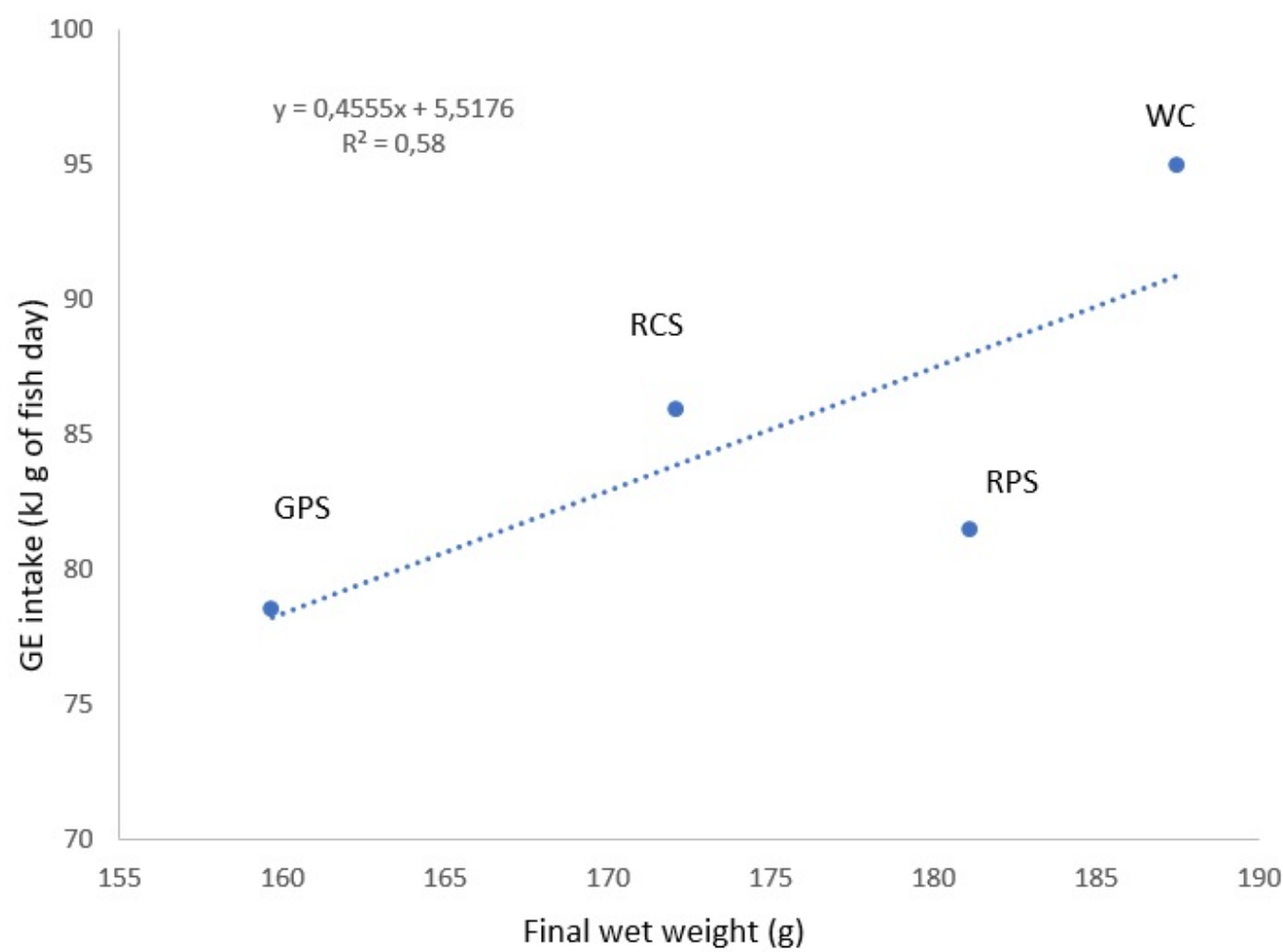

Figure 1. Correlation between final wet weight $(\mathrm{g})$ and ingestion rate $\left(\mathrm{kJ} \mathrm{g}\right.$ of fish ${ }^{-1}$ of the wild juveniles $E$. morio. Raw native cornstarch (RCS), waxy cornstarch (WCS), raw potato starch (RPS), gelatinized potato starch (GPS).

Table 2. Zootechnical parameters of wild juveniles of E. morio: initial and final wet weight, survival, thermal growth coefficient (TGC). Raw native cornstarch (RCS), waxy cornstarch (WCS), potato raw starch (PRS), gelatinized potato starch (GPS).

\begin{tabular}{lcccr}
\hline & RCS & RPS & WCS & GPS \\
\hline Survival \% & $100^{a}$ & $93.3 \pm 3.3^{a}$ & $100^{a}$ & $100^{a}$ \\
Initial wet weight (g) & $108.1 \pm 0.7^{a}$ & $111.8 \pm 0.7^{a}$ & $110.1 \pm 0.7^{a}$ & $105.6 \pm 0.7^{a}$ \\
Final wet weight (g) & $172.1 \pm 0.7^{a b}$ & $181.1 \pm 0.7^{a b}$ & $187.5 \pm 0.7^{a}$ & $159.9 \pm 0.7^{b}$ \\
TGC.day & $0.04 \pm 0.004^{a}$ & $0.032 \pm 0.004^{b}$ & $0.038 \pm 0.004^{a}$ & $0.034 \pm 0.004^{a b}$ \\
GE intake kJ fish $^{-1}$ day $^{-1}$ & $86 \pm 18^{a}$ & $81.4 \pm 3.4^{a}$ & $95 \pm 1.6^{a}$ & $78.6 \pm 3^{a}$ \\
\hline
\end{tabular}

*Different letters in superscript in the same row indicate significant differences. Mean \pm SE.

Table 3. Physiological parameters of E. morio fed different diets. Raw native cornstarch (RCS), waxy cornstarch (WCS), raw potato starch (RPS), gelatinized potato starch (GPS).

\begin{tabular}{|c|c|c|c|c|}
\hline & RCS & RPS & WCS & GPS \\
\hline Plasma glucose $\mathrm{mM}$ & $2.4 \pm 0.3^{a}$ & $2.3 \pm 0.3^{a}$ & $2.4 \pm 0.3^{a}$ & $2.5 \pm 0.3^{a}$ \\
\hline Liver glycogen $\mathrm{mg} \mathrm{g}^{-1}$ & $102 \pm 14^{b}$ & $75 \pm 14^{b}$ & $214 \pm 14^{a}$ & $96 \pm 14^{b}$ \\
\hline Hematocrit (\%) & $51 \pm 2^{a}$ & $50 \pm 2^{a}$ & $50 \pm 2^{a}$ & $51 \pm 2^{a}$ \\
\hline Hepatosomatic index & $2.1 \pm 0.3^{a}$ & $1.4 \pm 0.3^{a}$ & $2.1 \pm 0.3^{a}$ & $2.2 \pm 0.3^{a}$ \\
\hline
\end{tabular}

Hematocrit $=$ (viscera weight $/$ body weight $) \times 100 . \mathrm{HSI}=$ (liver weight $/$ body weight $) \times 100$. Significant differences in the same row are indicated by different letters (Tukey test, $\mathrm{p}<0.05$ ). Mean \pm SE 
In liver, metabolic enzymes of glycolytic pathway reacted according to the nature of starch significantly. HK1, HK2 and GK activities were significantly higher in fish fed raw cornstarch $(p<$ $0.05)$ but no difference appeared in fish fed waxy cornstarch ( $p>0.05)$. The lowest values were observed in fish fed gelatinized potato starch; however, no differences were observed in pyruvate kinase activity ( $p>0.05$, Table 4). FBPase activity was low in fish fed gelatinized potato starch $(p<0.05)$, and this was inversely correlated to alanine amino transferase activity, high in this same diet. By last, enzymes belonging to hexose monophosphate shunt presented the highest activity when fish received raw cornstarch $(p<0.05$, Table 4$)$.

\section{DISCUSSION}

This study demonstrated the ability of $E$. morio to incorporate dietary glucose from different starches to liver intermediary metabolism, in spite to its carnivorous habit and whose natural diet is constituted mainly on crustaceans, mollusks and fish (Giménez et al. 2001). The results of growth showed no significant differences between diets, estimated through thermal growth coefficient (TGC). That led all opportunity to examine the effect of carbohydrate from various origins on fish metabolism. Carnivorous fish received $20 \%$ inclusion level during $93 \mathrm{~d}$ with a glycaemia that remained relatively stable, suggesting that $E$. morio can regulate glucose homeostasis (Furuichi and Yone 1981) and metabolic aspects through phosphorylation and glycolytic pathway. In similar carnivorous species such as Salmo salar, Hippoglosus hippoglosus, Sparus sarba and $D$. labrax, GK activity had a fundamental role in the glucose regulation (Leung and Woo 2012, Viegas et al. 2015). Another parameter that could indicate that fish were healthy during the time of experiment was the hematocrit allowing eventually an interaction between nutrients in fish diets in captivity (Wahli 2002). Any change in hematocrit values may be a sign of immune-suppression; otherwise stress under hypoxia condition may lead to excessive erythrocytes amount that modify blood for- mula (Valenzuela et al. 2002). In this study, hematocrit values fluctuated around $50 \%$, and no significant differences between treatments were found. For red grouper in natural environment, hematocrit values have been reported around $40 \%$. It may be that under controlled condition (lower stress) fish fed a diet that covers its nutritional requirements produced a high hematocrit value (50\%).

A high assimilation of native cornstarch and waxy cornstarch in relation to the other dietary treatments was corroborated by TGC values; however, no differences were found in $\alpha$-amylase and $\alpha$-glycosidase activity between diets. But in the caeca, an increment of digestive activities was observed for all treatments. Wilson (1994) pointed out that a simple carbohydrate was absorbed quickly, producing hyperglycemia, unlike a starch digested slowly. Plasma glucose values were stable with all diets whatever starch origin. E. morio as a carnivorous species presented less $\alpha$-amylase compared to an herbivorous fish (Castillo et al. 2018), when fed corn starch small granules $(5-30 \mu)$. That would potentiate a hydrolytic activity, liberating glucose and activating glycolytic routes. The situation is different with large granules ( $100 \mu \mathrm{m})$ as in potato that reduced the rate of hydrolysis (Bello-Pérez et al. 1996). Native cornstarch with large granules size compared to potato starch possesses a greater contact surface area and produced a lower rate of enzymatic hydrolysis (Tester et al. 2004). Cornstarch granules had pores and channels that facilitated a diffusion of $\alpha$-amylase into the substrate and generate a diffused hydrolysis (Zhang et al. 2006). Native cornstarch containing small granules can induce HK-I, HK-II and free G-6P activities; therefore the most obvious result with carbohydrate utilization in $E$. morio recorded through enzymes activity is a control point to incorporate plasma glucose. By contrast, potato starch was digested by a process of exo-corrosion beginning in outer membrane to end up inside the granule (Tester and Karkalas 2006). Waxy cornstarch produced the highest weight gain, as a result of a positive energetic balance, and also higher glycogen content in liver. This starch rich in amylopectin (99\%) presents ramifications that allow 
Table 4. Specific activities ( $\mathrm{U}$ mg protein ${ }^{-1}$ ) of hepatic intermediary metabolic enzymes in wild juveniles $E$. morio. Raw native cornstarch (RCS), waxy cornstarch (WCS), raw potato starch (RPS), gelatinized potato starch (GPS).

\begin{tabular}{|c|c|c|c|c|c|}
\hline & $\begin{array}{l}\text { Enzymes } \\
\text { Acronym }\end{array}$ & $\begin{array}{c}\text { Raw } \\
\text { cornstarch }\end{array}$ & $\begin{array}{l}\text { Raw potato } \\
\text { starch }\end{array}$ & $\begin{array}{l}\text { Waxy } \\
\text { cornstarch }\end{array}$ & $\begin{array}{l}\text { Gelatinized } \\
\text { potato starch }\end{array}$ \\
\hline \multicolumn{6}{|l|}{ Glycolysis } \\
\hline Hexokinase-1 & HK 1 & $23.4 \pm 2.7^{a}$ & $2.1 \pm 2.7^{b}$ & $8.0 \pm 2.7^{a b}$ & $1.6 \pm 2.7^{b}$ \\
\hline Hexokinase-2 & HK 2 & $16.5 \pm 10.3^{a}$ & $1.8 \pm 10.3^{b}$ & $0.7 \pm 10.3^{a b}$ & $42.2 \pm 10.3^{b}$ \\
\hline Glucokinase & GK & $4.2 \pm 0.9^{a b}$ & $0.5 \pm 0.9^{c}$ & $5.2 \pm 0.9^{a}$ & $3.4 \pm 0.9^{b}$ \\
\hline Pyruvate Kinase & PK & $56 \pm 7.4^{a}$ & $18.7 \pm 6.5^{a}$ & $50.9 \pm 4.9^{a}$ & $9.1 \pm 1.7^{a}$ \\
\hline Gluconeogenesis & & & & & \\
\hline $\begin{array}{l}\text { Fructose-1,6-bisfosfatase } \\
\text { HMS or PPP }\end{array}$ & FBPase & $80.1 \pm 7.0^{a b}$ & $109.4 \pm 7.0^{a}$ & $80.6 \pm 7.0^{a b}$ & $66.0 \pm 5.8^{b}$ \\
\hline Glucose-6-phosphate dehydrogenase & G6P-DH & $40.0 \pm 5.5^{a}$ & $25.9 \pm 3.7^{a b}$ & $25.1 \pm 2.1^{b}$ & $26.7 \pm 3.3^{a b}$ \\
\hline 6-phosphogluconate dehydrogenase & 6-PGDH & $71.1 \pm 7.6^{a}$ & $57.0 \pm 4.9^{a b}$ & $61.1 \pm 5.6^{a b}$ & $45.3 \pm 5.02^{b}$ \\
\hline AA catabolism Alanine aminotransferase & ALAT & $10.5 \pm 6.2^{a b}$ & $8.1 \pm 7.9^{a b}$ & $3.0 \pm 1.4^{b}$ & $14 \pm 5.2^{a}$ \\
\hline
\end{tabular}

a better access via $\alpha$ (1-4) glycosidic linkages hydrolyzed by $\alpha$-amylase (Bello-Pérez et al. 1996).

The structure of cornstarch helped absorb granules and utilize starchy fraction as evidenced by HK-I and GK activation. 6PG-DH was more active in juveniles fed native raw cornstarch, which activated energy storage. Glycogen submitted to lipogenesis route lead to ribose-5P via pentose phosphate pathway route. In this sense, GK activity regulates glucose homeostasis in fish, in contrast with other hexokinases having a low affinity for glucose $(\mathrm{Km}$ $10 \mathrm{mM}$ ). This enzyme is not regulated by G6-P and acted only when plasma glucose concentration was high (saturated HK-I and HK-II). GK increased activity occurred with waxy cornstarch, same diet that produced the highest concentration of glycogen in fish. Additionally, PK acting as a third control point in glycolysis presented an increment of activity with raw cornstarch. In such treatment, fish produced enough G6-P substrate via the routes of energy storage: glycogenesis pathway and PPP that generates reducing compounds for unsaturated fatty acids and ribulose 5-P for tissue build-up. In addition, G6P-DH and 6PG-DH had the highest activity with raw cornstarch $(\mathrm{p}<0.05)$. E. morio could be using G6-P for glycolysis, store energy as glycogen form and increase in weight.

Fish in general have a limited tolerance to glucose; it has been shown that there are different factors that lead fish to have a poor utilization and storage capacity for glucose (Wilson 1994, Hemre et al. 2001). Carnivorous fish can tolerate up to $20 \%$ carbohydrate without problems of hyperglycemia. In salmonid (Cho 1992), seabream (Metón et al. 2003), tilapia and yellowtail (Shimeno et al. 1996), pompano (Chuanpeng et al. 2015), fish adapt their metabolism to compensate with dietary changes. Also, groupers assimilate carbohydrate, allowing energy balance to limit dietary protein utilization (Chen and Tsai 1994). Intermediary metabolism was affected by carbohydrate sources at three levels: glycolysis, gluconeogenesis and pentose shunt via (Méton et al. 1999). Fish fed native cornstarch activated glycolytic enzymes (HK-I, HK-II, GK and PK), driving more energy, to achieve its best weight gain values.

Gluconeogenesis is a preferred energy route for fish unlike mammals, using amino acid as substrate to obtain energy precursors: regulatory enzymes (FBPase) responsible to produce glucose de novo, from precursors such as lactate, amino acids, glycerol and fructose, gave an indication whether fish took substrates from protein as energy source. FBPase decrease in fish receiving diets containing raw or waxy cornstarch while glycolysis route being active. In this case, rainbow trout fed raw cornstarch increased enzymes of pentose's pathway (G6P-DH and 6-PGDH), favoring a source of NADPH (Hemre et al. 2001). As for glycolysis, fish fed raw potato starch produced a low GK activity, suggesting poor glucose utilization. 


\section{CONCLUSIONS}

The results showed that $E$. morio fed waxy or raw cornstarch presented the highest weight gain. All carbohydrate sources were well digested and blood glucose did not vary so far. There were differences at intermediary metabolic enzymes. Glucokinase activity was measured only in fish fed diets containing carbohydrate. Glycolysis was not influenced by carbohydrate accumulation and liver glycogen increased when $E$. morio received waxy and native cornstarch. These two diets increased activities of HK-I-II and GK. These results suggest that some starches contribute to regulate carbohy- drate metabolism. 6PG-DH increased in fish fed native cornstarch. Therefore, E. morio will cope with a metabolism based on waxy cornstarch containing amylopectin (99\%) and will be included in future studies as main carbohydrate source.

\section{ACKNOWLEDGEMENTS}

The authors wish to thank UNAM (IN 219713-3 project) for the financial support. To Karla Escalante, Jaime Suárez, Elisa Chan-Rivas, Korinthya López, Adriana Paredes for their technical support.

\section{LITERATURE CITED}

Amirkolaie AK, Leenhouwers I, Verreth JA, Schrama JW (2005) Type of dietary fibre soluble vs insoluble influences digestion, faeces characteristics and faecal waste production in Nile Tilapia (Oreochromis niloticus). Aquaculture Research 60: 1157-1166.

Bello-Pérez LA, Paredes-Lopez O, Roger F, Colonna P (1996) Molecular characterization of some Amylopectins. Cereal Chemistry 73: 12-17.

Bonamusa L, Garcia de Frutos P, Fernandez F, Baanante IV (1992) Nutritional effects on key glycolyticgluconeogenic enzyme activities and metabolite levels in the liver of the teleost fish Sparus aurata. Molecular Marine Biology and Biotechnology 12: 113-124.

Bradford M (1976) A rapid and sensitive method for the quantitation of microgram quantities of protein utilizing the principle of protein-dye binding. Analytical Biochemistry 72: 248-254.

Buleon A, Colonna P, Planchot V, Ball S (1998) Starch granules: structure and biosynthesis. International Journal of Biology and Macromolecules 23: 85-112.

Castillo A, Alvarez A, Cuzon G, Suárez J, Gaxiola G (2018) Glycemic response after glucose oral administration of wild juvenile red grouper Epinephelus morio fed two different diets. Fish Physiology and Biochemistry 44: $219-226$.

Chen HY, Tsai JC (1994) Optimal dietary protein level for the growth of juvenile grouper, Epinephelus malabaricus, fed semipurified diets. Aquaculture 119: 265-271.

Cho CY (1992) Feeding systems for rainbow trout and others salmonides with reference current estimates of energy and protein requirements. Aquaculture 100: 107-123.

Chuanpeng Z, Xianping G, Jin N, Heizhao L, Zhong H, Xiaohong T (2015) Effect of dietary carbohydrate levels on growth performance, body composition, intestinal and hepatic enzyme activities, and growth hormone gene expression of juvenile golden pompano Trachinotus ovatus. Aquaculture 437: 390-397.

Clark JE, McNaughton JE, Stark JR (1984) Metabolism in marine flatfish-I. Carbohydrate digestion in Dover sole (Solea solea L.). Comparative Biochemistry and Physiology 77B: 821-827.

Cowey CB, Walton MJ (1989) Intermediary metabolism. In: Halver JE (ed.) Fish Nutrition, Acad. Press, London. pp: 259-329. 
Daisley C (1973) Routine haematological methods from use with fish blood. Journal of Fish Biology 5: 771-778.

Dubois N, Kap LA, Lilies JC, Hamilton PA, Smith F (1965) Colorimetric method for determination of sugars of related substances. Analytic Chemistry 28: 350-356.

Enes P, Panserat S, Kaushik, S, Oliva-Teles A (2006) Effect of normal and waxy maize starch on growth, food utilization and hepatic glucose metabolism in European sea bass (Dicentrarchus labrax) juveniles. Comparative Biochemistry and Physiology 143: 89-96.

Enes P, García M, Guerrero A, Couto A, Pousaoud-Ferreira MA, Gallardo, et al. (2015) Utilization of dietary starch by juvenile white sea bream Diplodus sargus at different feeding frequencies. Aquaculture Nutrition 21: 926-934.

Fernández F, Miquel AG, Cordoba M, Varas M, Metón I (2007) Effects of diets with distinct protein-tocarbohydrate ratios on nutrient digestibility, growth performance, body composition and liver intermediary enzyme activities in gilthead sea bream (Sparus aurata L.) fingerlings. Journal of Experimental Marine Biology and Ecology 343: 1-10.

Furuichi M, Yone $Y$ (1981) Change of blood sugar and plasma insulin levels of fishes in glucose tolerance test. Bulletin Japanese Society Science and Fishery 47: 761-764.

Giménez E, Anderes B, Morena V, Burgos R (2001) Aspectos de la conducta alimentaria del mero Epinephelus morio del banco de Campeche. Ciencia Pesquera 15: 165-170.

Hemre GI, Mommsen TP, Krogdahl A (2001) Carbohydrates in fish nutrition: effects on growth, glucose metabolism and hepatic enzymes. Aquaculture Nutrition 7: 1-20.

Kirchner S, Seixas P, Kaushik S, Panserat S (2005) Effects of low protein intake on extra-hepatic gluconeogenic enzyme expression and peripheral glucose phosphorylation in RT (Oncorhynchus mykiss). Comparative Biochemistry and Physiology 140: 333-340.

Leung LY, Woo NYS (2012) Influence of dietary carbohydrate level on endocrine status and hepatic carbohydrate metabolism in the marine fish Sparus sarba. Fish Physiology and Biochemistry 38: 543-554.

Metón I, Fernández F, Baanante IV (2003) Short and long term effects of basal diet feeding on key enzyme activities in glycolysis-gluconeogenesis in the liver of gilthead seabream (Sparus aurata). Aquaculture 225: 99-107.

Peres H, Oliva-Teles A (2002) Utilization of raw and gelatinized starch by European sea bass (Dicentrarchus labrax) juveniles. Aquaculture 205: 287-299.

Ren M, Habte-Tsion HB, Xie J, Liu B, Zhou Q (2015) Effects of dietary carbohydrate source on growth performance, diet digestibility and liver glucose enzyme activity in blunt snout bream, Megalobrama amblycephala. Aquaculture 438: 75-81.

Robyt JF, Whelan WJ (1968) Amylases and their actions on starch. In: Radley JA (ed). Starch and derivatives. 4th Ed. Chapman \& Hall Ltd. London, UK. pp. 431-432.

Schmitt PD (1986) Feeding by larvae of Hypoatherina tropicalis (Pisces: Atherinidae) and its relation to prey availability in one Tree lagoon. Great Barrier reef. Australia. Environmental Biology of Fishes 16: 79-94.

Shimeno S, Hosokawa H, Takeda M (1996) Metabolic response of juvenile yellowtail to dietary carbohydrate to lipid ratios. Fishery Science 62: 945-949. 
Silva AF, Escalante K, Alvarez-González CA, Guerrero-Olazarán M, Cuzon G, Gaxiola G (2014) Protein digestibility by in vitro and in vivo methods in red grouper Epinephelus morio. The Israeli Journal of Aquatic-Bamidgeh 64: 1069-1081.

Tester RF, Karkalas J, Qi X (2004) Starch Composition, Fine Structure and Architecture. Journal of Cereal Science 39: 151-165.

Tester RF, Karkalas J (2006) Hydrolysis of native starches with amylases. Animal Feed Science and Technology 130: 39-54.

Tranulis MA, Dregni O, Christophersen B, Krogdahl A, Borrebaek B (1996) A glucokinase-like enzyme in the liver of Atlantic salmon (Salmo salar). Comparative Biochemistry and Physiology 114B: 35-39.

Tharanathan R (2002) Food-derived carbohydrates structural complexity and functional diversity. Critical Reviews in Biotechnology 22: 65-84.

Valenzuela AE, Alveal KI, Tarifeño E (2002) Respuesta hematológica de truchas (Oncorhynchus mykiss Walbaum 1792) a estrés hipóxico agudo. Gayana 6: 255-261.

Viegas I, Rito J, Jarak I, Leston S, Caballero-Solares A, Metón I, et al. (2015) Contribution of dietary starch to hepatic and systemic carbohydrate fluxes in European seabass (Dicentrarchus labrax L.). British Journal of Nutrition 113: 1345-1354.

Wahli T (2002) Approaches to investigate environmental impacts on fish health. Fish Biology 24: 545-552. Wilson RP (1994) Utilization of dietary carbohydrate by fish. Aquaculture 124: 67-80.

Zhang J, Li A, Wang A (2006) Study on superabsorbent composite. VI. Preparation, characterization and swelling behaviors of starch phosphate polyacrylamide/attapulgite super absorbent composite. Carbon Polymers 65: 150-158. 